\title{
Women Language in Indonesian Television Talk Show
}

Fauziah Khairani Lubis ${ }^{1}$ \& Syamsul Bahri ${ }^{2}$

${ }^{1 \& 2}$ Universitas Negeri Medan, Indonesia

\begin{tabular}{|c|c|}
\hline ARTICLE INFO & ABSTRACT \\
\hline Article history: & \multirow{5}{*}{$\begin{array}{l}\text { This study was aimed at analyzing the Women Language in } \\
\text { Indonesia by three Television Talk Show with female hosts in a } \\
\text { different context. There are Mata Najwa in politics, Marry Riana in } \\
\text { Social, and Feni Rose Widyadhari, Rumpi in entertainment. The } \\
\text { analysis is based on the utterances of female hosts, so all objects in } \\
\text { this research are Women. The findings of this research show that } \\
\text { there are } 39 \text { times of lexical hedges or fillers, tag questions } 17 \text { times, } \\
\text { rising intonation on declarative } 19 \text { times, empty adjectives } 6 \text { times, } \\
\text { intensifiers } 26 \text { times, hypercorrect grammar } 13 \text { times, super polite } \\
\text { forms } 3 \text { times, avoidance of strong swear words only one, and } \\
\text { emphatic stress } 24 \text { times occurs in } 3 \text { different talk shows. This study } \\
\text { shows that women's language mostly used the kind of Lexical hedges } \\
\text { or filler in the utterance to have a purpose in giving a sequence time } \\
\text { to think what they will say next in the talk show. }\end{array}$} \\
\hline $\begin{array}{l}\text { Received Aug 10, } 2020 \\
\text { Revised Aug 20, } 2020 \\
\text { Accepted Sept 19, } 2020\end{array}$ & \\
\hline Keywords: & \\
\hline $\begin{array}{l}\text { Female Hosts, } \\
\text { Television Talk Shows, } \\
\text { Women Language, } \\
\text { Indonesia, }\end{array}$ & \\
\hline & \\
\hline
\end{tabular}

None

\section{Funding:}

None

Corresponding Author: Fauziah Khairani Lubis. State University of Medan. Email: syamsul.bahri0401@gmail.com

(C) (O) $\begin{aligned} & \text { (C) Fauziah Khairani Lubis, Syamsul Bahri } \\ & \text { This is an open access article under the CC BY-SA 4.0 international license. }\end{aligned}$

\section{Introduction}

Language is an instrument to communicate in society. There is a society, of course, there is a language and if there is no society, the language cannot be found. It means that language has interrelated with various components of human life. This also consists of the branch of linguistics referred to as Sociolinguistics. Sociolinguistic research the relationships between language and society. People have their methods to use a language. The preceding researcher Wardaugh (2006: 121) argued a language that people use in their day by day existence is now not targeted by means of linguistic factors however also social elements such as education, social status, age, sex, or gender might also have an effect on or decide the language used. Men and women tend to use exclusive variants of languages.

In the globalization era, women's emancipation has changed the mindset of women in the world. Many women do the same as men do in daily activity. The influence of women emancipation in Indonesia might also supply affect on girls nowadays in more than a few factors such as profession or job, acknowledgment, the recreation in society. Holmes $(2013: 61)$ states that the shift to some other language may be led by using girls or by means of guys depending on the place the new jobs lie and the gender roles in society. It capability that the work environment influences the use of language. The researcher focuses on phenomena in the society the place girls do their pastime which is different from their ordinary motion or role as ladies as common in society due to the fact of the have an impact on of technological know-how and globalization. The researcher used five previous relevant studies to support this research, there are: 1) Md Nesar Udin \& Mahmuda Sarmin (2019) entitled "The Role of Gender in TV Talk Show Discourse in Bangladesh: A Conversational Analysis of Hosts' Interaction Management" 2) Hafiz Ahmad Bilal et al (2012) entitled" 
Critical Discourse Analysis of Political TV Talk Shows of Pakistani Media" 3) Kate McKluskie (1983) entitled "Women's Language and Literature: A Problem in Women Studies" 4) Engin Evrim Onem (2016) entitled "A study on gender differences in the length of requests in Turkish" 5) Luh Putu Laksminy et al (2019) entitled "Creating Pseudo-intimacy Through Vocatives in Indonesian TV Show".

\section{Literature Review}

\subsection{Language and Gender}

In terms of sex and gender in Sociolinguistics, Holmes (2013:159) has used the term gender alternatively than sex because sex refers to categories distinct by way of biological characteristics, whilst gender is greater fantastic for distinguishing human beings primarily based on their Socio-cultural behavior, together with speech. In some languages, there are also variations between the vocabulary used by using women and men. The variations of Gender in language are frequently simply one factor of more pervasive linguistic variations in society reflecting the status of society or variations of power. Women and men have a tendency to use language differently. In different words, women and men have their version of saying things. Although women might also have a tendency to discuss distinctively (though this will constantly differ with context, one contextual factor being one's interlocutor or co-conversationalists), they may also also speak differently in conversation with women than with men, Jane Sanderlan (2014:18).

The subject matter of the variations between men and women turns into an pastime in human species and supposed linguistic variations are regularly perpetuated in proverbs. Most language trade takes place in unplanned methods and about which there is very little public or aware recognition and most studies of alternate are not involved with mindful intervention. Holmes 2013:61) mentioned that gender roles in society have an affect on the user of language. Generally, women are extra talkative than men in society due to the fact of some elements such as biological, position gender, and job. However, the previous researcher Li (2014:56) located that men are extra talkative than women on some occasions.

According to Holmes (2013:167-170), there are four explanation of why women speak differently:

1.Social status

Women know more about speech signals social status and background rather than men. Some women use more standards forms to signals high social status and some of them lack social prestige, so they use these forms to acquire it.

2.Women's role as guardian of society's value.

Most women are expected to have better behavior rather than men in society, and society expects them to be modeling correct behavior.

3.Women's status as a subordinate group.

Women always speak carefully and politely as a subordinate group. Most of the women protect her face as a standard form (a technical term used by Sociolinguistics with approximately the same meaning as in the phrase to lose face). A woman usually avoids offense to the other people. Suggesting that a woman who uses standard forms to protect her 'face' is not very different from saying she is claiming more status than she is entitled to, compared to men from the same social group.

4.Speech express masculinity

Men carry macho connotations of masculinity and toughness, meanwhile, women tend to utilize more standard forms.

Beside four explanations of why women speak differently, Holmes (2013:171-174) argued that there are other explanations about why women speak differently.

1.Women categorization

Linguists classify women according to their husbands' social class. For example, sometimes a woman is better educated than her husband and then she speaks differently, using more standard forms than he does. Because of this miscategorization, we rely on the differences in their speech as the man uses more vernacular than the woman.

2.Interviewer and context influences 
People tend to accommodate the speech of the interviewer who is usually from the middle class. Because women are more cooperative conversationalists than men. To establish speech accommodation, women usually tend to utilize the standards forms.

3. Gender of the speaker itself may override other social factors

In some communities, being man or woman influences speech and is the reason for speech variation between men and women. Multiple negations and forms like (ain't) is usually used by males, while, females used less of these forms. Gender is the explanatory factor for different speech patterns

\subsection{Women's Language Features}

Lakoff(1973) in Holmes's book (2013:302) divided ten types of women's language features such as lexical hedges or fillers, tag questions, rising intonation on declarative, 'empty adjectives, precise color terms, intensifiers such as just and so, 'hypercorrect' grammar, 'superpolite' forms, avoidance of strong swear words, and emphatic stress.

a. Lexical Hedges or filler

Women's speech is often described as 'tentative', and this assertion is linked to the claim that women use more hedges (Coates 2013:88). Lakoff decided hedging as one of the characteristics of women's speech features. Holmes said that some researchers reported that women used up to three times as many hedges as men, while in others there were no differences between the sexes.Lexical Hedges or filler Are expressions such as "well", "you know", "kinda", "I think", "hmm", "umm" etc. For example: "So, hmm are you enjoying your leisure in Bandung this time?" (to give the speakers time to think)

\section{b. Tag Question}

Lakoff (1975) stated that "to express uncertainty, tag question is utilized". The function of the tag question is to emphasize the speaker's speech and make the audience or reader more believe in the speaker's speech For example:" So he is pretty cool, right?" (right in here function as emphasize)

\section{c.Rising Intonation on Declarative}

Women tend to use rising intonation on declarative to make sure the accuracy of information". Lakoff (1975:17). Rising intonation usually used by them who wish to continue speaking, seek feedback or response, or feel uncertain about their statement. Wardhaugh (2006: 321) states that the intonation patterns of men and women are different. women using certain rising patterns combined with surprise and politeness more often than men. The function of Rising intonation on declarative is to get a response from the addressee and to deemphasize or emphasize the fact. For example: "it's very good." ("Good" indicates rising intonation)

d.Empty Adjective

Empty adjective or called Feminine Adjectives conveyor describes an emotional reaction than specific information. A word categorized as an empty adjective since its employment is not significant to the main information of the conversation and employed only to make the utterance sound good. Lakoff (1975) stated that a great many words had affective meaning to expressing feelings, not referential meaning referring to some object or state of affairs. Adjectives such as divine, adorable, charming, are strongly marked as feminine. For example: "I do not think it is very pretty“ (Very pretty is Emotional reaction than specific information)

\section{e. Precise color terms}

Women make far more precise discrimination of color than men. This is called women 's color variation. The more specific one is about color terms, women claim that those color terms to be commonly used, but they are seen not real for men. The function of precise color terms is to make the conversation simpler, it reflects that women have nature knowledge in their mind about naming colors and to prove that women have more vocabularies than men. For example: "I like that rose shoes" (rose is red in the general term of color)

\section{f. Intensifier}

The intensifier is elements that are used with other expressions to indicate an attempt to intensify the meaning of the expression they modify. The function of the intensifier is to strengthen the words that have different things or specialty to be expressed or hyperbole. For example: "This is a very big day, girl" (use intensifier feature by employing the word 'very'. Actually, the word 'very' can be omitted without violating the main meaning of the statement.)

g. 'Hypercorrect' Grammar 
Hypercorrect grammar phenomenon is also referred to as the way of women in reminding others about the correct form. It means that slang and vulgar words or expressions are avoided and consistency use standard verbs form. The function of hypercorrect grammar is to make the listener or reader feel comfortable and to hold on well the relationship. For example:" I do not know about it" (Women avoids 'don't,)

h. 'Superpolite' Form

The language used by women generally contains more super-polite forms. In other research in line with Lakoff's theories state that women are often believed to be less self-confident than men. According to Lakoff (1975:56) "Women are believed to be experts of euphemism and know how the right things to say to other people". The function of the super polite form is to ask the addressee politely and to soften an utterance. For example: "Oh. Well, I really wish you would get me to see the floating lights." (she can employ simpler expressions such as 'I want you to'.)

i. Avoidance of strong swear words

Women tend to avoid using strong swear words and replace it with a weak expletive or softer swear words in other to maintain their politeness. The function of avoidance of strong swear words is to emphasize or strengthen the expression of the speaker's opinion. For example: "oh my gosh," (include in softer swears and avoid strong swears word)

\section{j. Emphatic Stress}

This feature is used by women to express uncertainty with women's self-expression. Women use this feature to show more stress or emphasize and strengthen the words. Emphatic stress is the stress that used to strengthen the statement or utterance. It occurs when women want to strengthen an assertion. For example: "it was a brilliant performance?" (to give more emphasize or strengthen those words).

\section{Method}

This research makes use of descriptive qualitative technique as a strategy for exploring and understanding the which means people or corporations ascribe to a social or human problem. The process of lookup entails eme rging questions an procedures, data generally accumulated in the participant's setting, records analysis induct ively constructing from particulars to prevalent themes, and the researchers making interpretations of meanin $\mathrm{g}$ the records (Creswell, 2014).

This research presents the analysis of women language in Indonesian Television Talk Show with female host $\mathrm{s}$ in different context, they are Mata Najwa in politics, Marry Riana in social and Feny Rose Widyadhari, Ru mpi in entertainment. The analysis is based on the utterances of female hosts, so all object in this research are women. The data are transcribed and classified into ten types of women language feature. In analyzing the da ta, the writer would you like to interpret the data contextually and elaborate them theoretically.

\section{Results and Discussion}

\begin{tabular}{llccccc}
\hline NO. & $\begin{array}{l}\text { Women's Language } \\
\text { Features }\end{array}$ & Mata Najwa & Rumpi & $\begin{array}{l}\text { Merry } \\
\text { Show }\end{array}$ & Total & Percentage \\
\hline 1 & $\begin{array}{l}\text { Lexical Hedges or } \\
\text { Filler }\end{array}$ & 14 & 19 & 6 & 39 & $26,3 \%$ \\
\hline 2 & Tag Question & 6 & 7 & 4 & 17 & $11,4 \%$ \\
\hline 3 & $\begin{array}{l}\text { Rising Intonation on } \\
\text { Declarative }\end{array}$ & 11 & 5 & 3 & 19 & $12,8 \%$ \\
\hline 4 & Empty Adjective & - & 3 & 3 & 6 & $4 \%$ \\
\hline 5 & Intensifier & 7 & 7 & 12 & 26 & $17,5 \%$ \\
\hline 6 & $\begin{array}{l}\text { Hypercorrect } \\
\text { Grammar }\end{array}$ & 13 & - & - & 13 & $8,7 \%$ \\
\hline 7 & Super-polite Form & 2 & - & 1 & 3 & $2 \%$ \\
\hline 8 & $\begin{array}{l}\text { Avoiding } \\
\text { Swear Word }\end{array}$ & - & 1 & - & 1 & $0,6 \%$ \\
\hline 9 & Emphatic Stress & 14 & 5 & 5 & 24 & $16,2 \%$ \\
\hline
\end{tabular}

\subsection{Lexical Hedges or Filler}


Lexical Hedges or filler are expressions such as "well", "you know", "kinda", "I think", "hmm", "umm” etc, Holmes (2013:302-303) . The Function of lexical hedges or filler is to shift a topic, to express uncertainty and lack of confidence, to differentiate one topic from another, and as a filler in the conversation, it gives the speakers sequence time to think, to keep the conversation still on the track.

Example 1

Najwa: "bukan menjawab soal. Mmm tadi anda menyebut orang tua juga ikut stress. saya ingin ke salah seorang orang tua malam ini hadir adalah pak Giono. Selamat malam pak Giono, terimakasih sudah hadir di mata najwa, jadi putra putri anda ada tiga ya pak? kelasnya mana saja tu pak, level tingkat pendidikannya pak?"

Pak Giono: "yang anak pertama di perguruan tingi, yang kedua SMK kelas III, kemudian yang terakhir itu kelas I SMK baru masuk kemaren. “

Najwa: "baru masuk"

In the conversation, Najwa repeated the statement from Ibu Retno who was one of the participants in the event and then ask one of the other participants. in his speech, Najwa asked about the education of the participant's children and the participant answer the questions given by Najwa, when Najwa repeated the statement, there is a filler in her utterance.

Mmm, tadi anda menyebut orang tua juga ikut stress. "Mmm" in her utterance, to give a sequence time to think what she will say next, she used lexical hedges or filler on that purpose. "Mmm" in her utterance purpose to remember the statement. "Mmm" or Filler assists the presenter to think or to remember many things quickly.

\subsection{Tag Question}

According to Lakoff (1973:54), There are situations in which a tag is legitimate, in fact, the only legitimate sentence-form.first tag-question used in cases where the speaker knows as well as the addressee what the answer must be, and doesn't need confirmation or respond. Second, use in discussing personal feelings or opinions, only the speaker normally has any way of knowing the correct answer. Third, where it is the speaker's opinions, rather than perceptions, for which corroboration is sough.

Example 1

Najwa: tapi sekarang standarnya itu berbeda beda kan pak? setiap kota saja itu standarnya beda-beda sekolahnya

Sudewo: situasi dan kondisi pasti berbeda-beda tetapi pasti harus dikasi standar agar memacu sekolah tersebut naik ke standar lebih tinggi

Najwa: gimana mas Tino?

This conversation between female and male. Najwa who the presenter in this event asked the informant in this conversation about the standard of education in school. The informant answered the question that every school has a different quality in the standard of education. Based on the statement from the informant, Najwa asked the opinion from the participant in the event

"Tapi sekarang standard itu berbeda beda kan pak?" in this utterance by Najwa, indicated Tag Question purpose to emphasize what the speakers are talking about. In the utterance, "kan" emphasizes the speaker's statement. Najwa emphasizes her utterance to strengthen the statement from the informant.

\subsection{Rising Intonation on Declarative}

Rising intonation usually used by them who wish to continue speaking, seek feedback or response, or feel uncertain about their statement. Lakoff (1973:17) argued that women tend to use rising intonation on declarative to make sure the accuracy of information".

Example 1

Buk Retno : yang pertama adalah menurut saya ini yaa orang tua juga stress biaya juga tinggi karena anakanak juga bimbel dan yang menurut saya lebih ini adalah anak-anak kita tu jadi belajar menghafal memang jadi dari awal pendidikan kita tu seolah-olah untuk menjawab soal padahal menurut Kyai Hajar Dewantara kalau kita mennggunakan cara belajar Kyai Hajar sekolah bersekolah itu adalah mengajarkan cara berfikir, bernalar bukan menghafal dan bukan menjawab soal. 
Najwa: bukan menjawab soal. Mmm tadi anda menyebut orang tua juga ikut stress saya ingin ke salah seorang orang tua malam ini hadir adalah pak Giono, selamat malam pak Giono, terimakasih sudah hadir di mata najwa, jadi anda putra putri ada tiga ya pak? kelasnya mana saja tu pak, level tingkat pendidikannya pak?

This conversation between the presenter and the participant in this event. The participant gave her opinion about what is education. She describes that education is a garden and study or education should fun and not make the student stress. Najwa heard about the statement repeated the statement with rising intonation.

"Bukan menjawab soal." Indicated rising intonation on declarative in Najwa Utterance. Najwa repeated the statement from the participant by using rising intonation on declarative in her utterance purpose to deemphasize or emphasize the fact. The rising intonation emphasizes "Bukan Menjawab Soal".

\subsection{Empty Adjective}

Lakoff (1973:51) states that there is a great word had affective meaning to do with expressing feelings, not referential meaning referring to some objects or state of affairs. Empty adjectives indicated the speaker's approbation or admiration for something, such as lovely, pretty, sweet, etc. Some of these adjectives are neutral as to the sex of the speaker. Either men or women may use them. But another set seems, in its figurative use, to be largely confined to women's speech.

Example 1

Merry: tapi pernah ga sih mbak Meira ngeras insecure dari segi cinta

Meira : kalau segi cinta aku tu pacaran sama Eren itu 5 tahun kalau pernikahan itu udah 11 taun jadi udah 16 taun udah lama bareng jadi ngerasa insecurenya itu udah ilang, ga ada lagi, insecure itu ngerasa kalau kita kayak apakah kita pantas untuk orang ini karna memang tuntutannya itu jauh lebih besar dari pada laki-laki misalnya kita pacaran ni sama cowo, dan cowo ini tuh lebih good looking lah dari kitakan, nahh itu berat banget karna akan ada banyak judge, kayak "ih ini cewe lo" atau dari keluarga "lu bisa dapet yang lebih dari dia" kek gitu nah memang sayangnya di culture kita ini masih sangat mementingkan penampilan luar, jadi yang kayak cantik dari hati nahh itu tu cuman jadi slogan doang. Padahal yang terjadi ketika kita mencari pasangan dari hanya fisik dari luar saja itu mungkin satu dua tahun okay, kalau untuk yang seumur hidup sama sekali enngak. Kalau aku sama suami itu lebih prefer ke orang yang cocok karna penampilan luar itu bisa berubah loh. Sometimes orang saat ini begini suatu saat pasti bakalan berubah. Tapi kalau kita punya kecocokan yang sama, hobi sama, atau dia ngertiin aku, aku juga ngertiin dia juga nah itu kan bisa saling melegkapi, dan perasaan itu bisa terus tumbuh dan long last, ya gitu sayangnya perempuan bakal yang jadi berat.

In the conversation between Meira and Merry in the talkshow, Merry asked about insecure in her personality. Meira answered the question and explained how insecure herself in daily life. She explained about her culture that good looking is an important thing in society.

"jadi yang kayak cantik dari hati nahh itu tu cuman jadi slogan doang." indicated empty adjective in Meira's utterance. The utterance "cantik", has a purpose to create more emphasizes on what the speaker said. She emphasizes that good looking is the number one thing in society. She used empty adjectives (cantik) to emphasize her self that she is the victim of social discrimination.

"Orang ganteng belum tentu istrinya cantik" this is similar to the previous example where cantik indicates empty adjective. She used empty adjectives in her utterance to give more emphasis on what the speaker said. She used empty adjective in her utterance according to hater's comment in Instagram

\subsection{Intensifier}

The intensifiers are used more frequently by women than men. Unlike lexical hedges, intensifiers (e.g. so, really, very) are used as boosting devices to strengthen the intended meaning, Holmes (2013:302).

Example 1

Pak Toto: ya kalau saya praktek UN yang selama ini telah mereduksi proses pendidikan hanya trill bahkan hanya membawa keseharian yang assesment yang dilakukan guru itu mengarah ka UN, pilihan ganda banyak hafalan, tidak melatih penalaran padahal.

Najwa: betul seperti itu temen-temen? akhirnya belajar hanya menghafal-menghafal saja ya?

Sophia: tadikan si adik ini sudah menyebut saya mencari soal, soal, soal, untuk dia yang dicarikan hanya soal 
The conversation in this example between two participants and the presenter in the show. The male participant gave his opinion about the national exam that the national exam only decreases the mindset of the student. this statement makes the presenter repeated his statement to discuss in further.

"Betul seperti itu temen-temen? akhirnya belajar hanya menghafal-menghafal saja ya?" indicated Intensifier in Najwa's utterance. The intensifier purpose to emphasize or strengthen the words that have different things. The presenter used an intensifier in her utterance to strengthen the participant's statement about education.

"Ketika waktu itu terjadi ya gila sedih banget sih, kek kok orang bisa sejahat itu ya gitu." Meira's utterance indicated Intensifier that purpose to be expressed or hyperbole. She expressed stress out because of the bully in the society about her fashion and physic.

\subsection{Hypercorrect’ Grammar}

Hypercorrect grammar phenomenon is also referred to as the way of women in reminding others about the correct form. It means that slang and vulgar words or expressions are avoided and consistency use standard verbs form. The function of hypercorrect grammar is to make the listener or reader feel comfortable and to hold on the relationship well.

\section{Example 1}

Najwa: ya itu tadi suara guru ada yang sepakat dan ada yang tidak sepakat saya ingin bertanya kepada kepala dinas pendidikan kota Bekasi, ada pak Ilnayatullah, selamat malam pak terima kasih sudah datang, sesungguhnya yang nanti akan menjalankan ini ada di kepala dinas dan pemerintah daerah. Saya tau anda termasuk salah satu yang tidak sepakat sesungguhnya UN itu diganti apa alasan anda?

Inayatullah: yaa terimakasih mbak najwa, memang pada dasarnya kalau UN dihapus, dilapangan didinas pendidikan, kalau rancangannya sudah jelas dan UN mau dihapus atau di ganti ya monggo yang penting ada parameter untuk mengukur bagaimanasiswa itu bisa belajar dengan motovasi sendiri sehingga tertarik. Karna dilapangan termasuk UN kadang-kadang kurng motivasi nah ini, oleh karena itu kalau di ganti harus ada yang lebih baik lagi

Najwa starts the talk show and then asked the government participant from bekasi about National Exam. Najwa gives a chance to the participant to give his opinion in the talk show. The participant rejected if national exam erased from the world of education because without national exam, there is no motivation to study

"ada pak Ilnayatullah, selamat malam pak terima kasih sudah datang, sesungguhnya yang nanti akan menjalankan ini ada di kepala dinas dan pemerintah daerah." Indicated hypercorrect grammar in Najwa's utterance. The speaker used hyper-correct grammar in the utterance to make the listener or reader feel comfortable. This occurs when the speaker wants to appreciate the participant.

\subsection{Super-polite Form}

According to Lakoff (1973:56) leaving a decision open, not imposing your mind or views, or claims, on anyone else. A tag-question is, of course, a kind of polite statement that does not push an agreement or belief to the addressee. Otherwise, the same sense a polite command in a request does not overtly require obedience, but rather suggests something done as a help to the speaker. An indirect speech of Super polite form stating in a request, command, and statement.

\section{Example 1}

Najwa: Menguji ujian nasional itu topik mata najwa pada malam hari ini, tadi saya sudah membuka dengan mendengarkan curhatan adik-adik, ada dari madrasah, SMA, dan SMK bagaimana stressnya mereka menghadapi UN. Saya akan perkenalkan tamu-tamu saya yang lain ada PLTD JENDIKNAS KEMENDIKBUD Pak Toto Suprayetno terima kasih sudah hadir pak Toto

Najwa opened the talkshow after listened students opinion. The presenter introduces the participants in the talkshow. the first guess from the talkshow is PLTD Jendiknas Kemendikbud as the participant in the talkshow with the topic National Exam.

"ada PLTD JENDIKNAS KEMENDIKBUD Pak Toto Suprayetno terima kasih sudah hadir pak Toto" indicated super-polite form in the presenter's utterance. The speaker used super-polite form in her utterance to Soften an Utterance. This helps the speaker to give appreciation to the participant politely.

\subsection{Avoiding Strong Swear Word}

Women tend to avoid using strong swear words to maintain their politeness. Women tend to avoid using 
strong swear words and replace them with a weak expletive or softer swearwords. It is because women are encouraged to act like a lady since they were young.

Example 1

Luna: apaa yaaa aduhhhhh bisa pas gak?

Fenyrose: okay diganti 3 sifat yang tidak bisa kamu jadikan teman?

Luna: ooo munafik, suka bohong, trus nyinyir.

The conversation in gosip talk show, this conversation between Luna and Fenny. Fenny asked Luna about something, and Luna must answer all of the questions in 60 seconds as the game in the talk show. When the speaker asked about 3 characteristics about friendship, Luna answered the question she is not like a fake and liar friend.

"Ooo munafik, suka bohong, terus nyinyir" the guest of the talk show used avoiding strong swear words in her utterance. This occurs when the speaker or the presenter of the talk show asked about personality. The guest kept answered the question instantly as part of the talk show. The guest used avoiding strong swear word in her utterance to emphasize or strengthen the expression of the speaker's opinion

\subsection{Emphatic Stress}

According to Lakoff (1973:74) emphatic stress may be used for hedging or reducing the force of utterance or the features may boost or intensify the proportion of a force.

\section{Example 1}

Najwa: untuk UN, okay baik ini ni baru satu kisah mbak sophi saya minta anda komentar, anda dari tahun 2006 juga selalu teriak-teriak soal UN ini

Sophia: iya saya juga lupa kenapa saya bisa terbit yaa $\mathrm{mmm}$ dan disitu juga $\mathrm{UN}$ adalah penentu kelulusan $100 \%$, banyak sekali anak-anak yang eee ya saya bilang korbannya gitu hampir setiap hari ada anak yang dateng SMP, SMA bahkan ada anak yang ee International Science champion yang tidak lulus SMA ya kalau tidak salah

Buk Retno: padahal nilainya 9 waktu itu hanya matematikanya aja, matematikanya tidak sampai 4 dan dia tidak lulus

In this conversation between female in the talkshow. Najwa as the presenter give a chance to Sophia to give her opinion about education in indonesia. sophia said that there are so many student ablities decrease because the national exam and then Retno repeated the Sophia's statement

"padahal nilainya 9 waktu itu hanya matematikanya aja, matematikanya tidak sampai 4 dan dia tidak lulus" indicated emphatic stress in the participant's utterance. The previous participant gave her opinion and fact about education and national exam in Indonesia. As the same participant, she repeated the previous participant's statement to emphasize the previous participant's statement. The participant used emphatic stress to strengthen the statement or utterance.

\section{Conclusion}

The women's language features used in the three different talk shows are there were nine types of women's language features. They are lexical hedges or fillers, tag questions, rising intonation on declarative, empty adjectives, intensifiers, hypercorrect grammar, super polite forms, avoidance of strong swear words, and emphatic stress. One of the features that do not occur is the precise color term. It happens because there is no relevant topic about color in the talk show. It can be seen in the diagram below: 


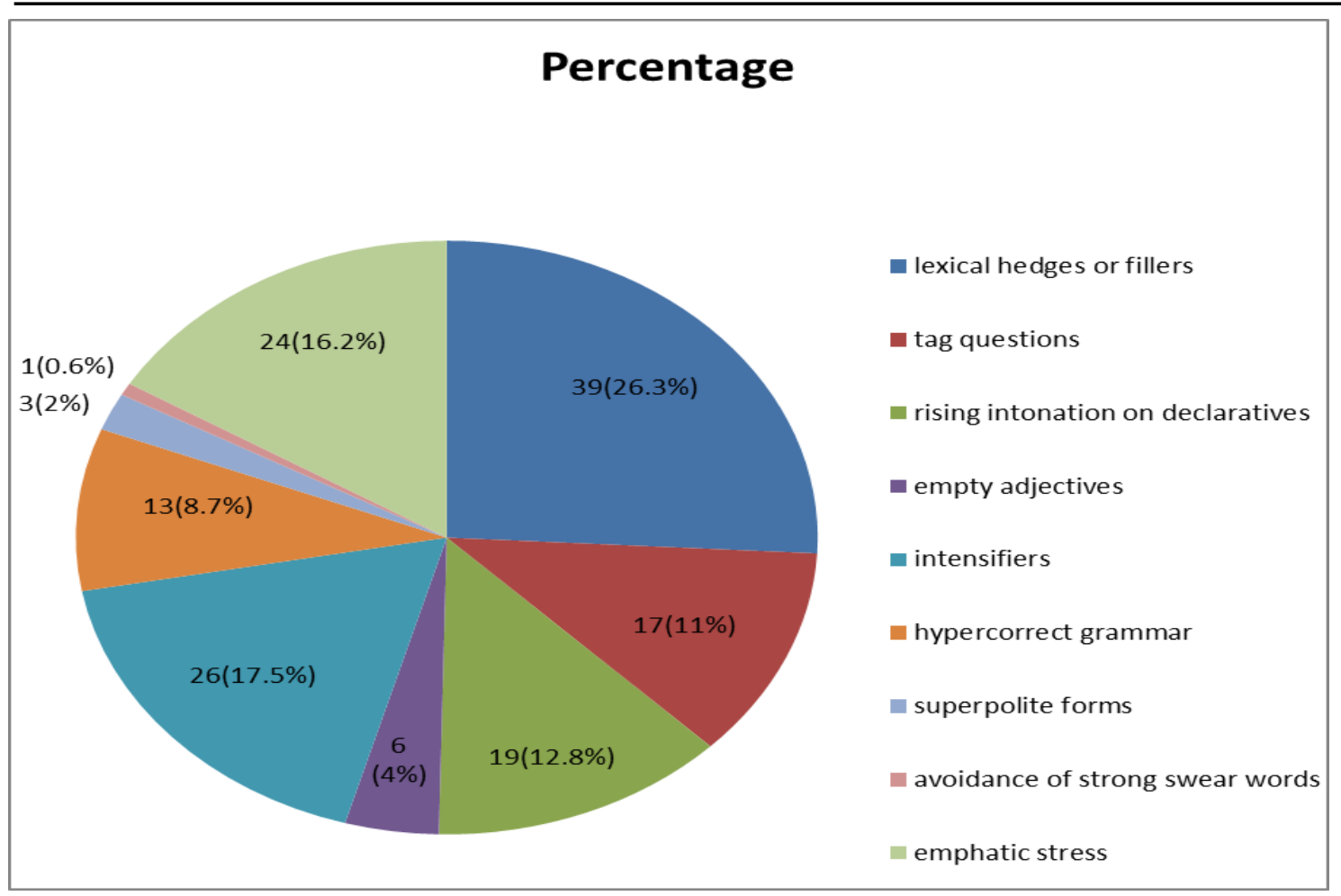

Based on the data above, lexical hedges or fillers 39 times are found, tag questions 17 times, rising intonation on declarative 19 times, empty adjectives 6 times, intensifiers 26 times, hypercorrect grammar 13 times, super polite forms 3 times, avoidance of strong swear words only one, and emphatic stress 24 times occurs in 3 different talk show.

In Mata Najwa, female speakers often used lexical hedges and emphatic stress in their utterances. Lexical hedges purposed to give the speaker time to think when the speaker wants to state an opinion. Emphatic stress purposed to strengthen the opinion or a statement to the addressee so that the audience thinks that her opinion has a fact. In Rumpi Entertainment Show, the master of ceremony and the guest star in this show often used lexical hedges. This happened because the master of ceremony often asked the quest star privacy question so that the guest star often used lexical hedges or filler to give time to think what should guest star say. In Marry Riana Show, the master of ceremony and the guest star in the show often used intensifiers in their utterances. Intensifiers often used in this show because they often expressed their feeling about something. This purpose to emphasize their utterance or expressed a hyperbole.

Overall, Lexical hedges or filler in the utterance purpose to give a sequence time to think what they will say next. Tag question in the utterance to emphasize what the speakers are talking about. Rising intonation in the utterance to deemphasize or emphasize the fact. Empty adjective purpose to give more emphasis on what the speaker said. Intensifier in the utterance purpose to emphasize or strengthen the words that have different things or hyperbole. Hypercorrect grammar purpose to avoid a gap Between addresser and addressee. Super polite form in the utterance to soften an Utterance. Emphatic stress to strengthen the statement or utterance.

\section{References}

Bilal, Hafiz Ahmad et al. (2012). Critical Discourse Analysis of Political TV Talk Shows of

Pakistani Media. International Journal of Linguistics. Vol 4 (1).

www.203macrothink.org/ijl

Creswell, J. W (2014). Research Design Quality, Quantitaive and Mixed Methods Approaches. Los Anglos: SAGE Publication, Inc.

Laksminy, Luh Putu et al. (2019). Creating Pseudo-intimacy Through Vocatives in IndonesianTv

Show. IJLLT. Vol 2 (3). www.ijllt.org

Mazda, Lucy. (1999). The Television Talk- Show in France: Constructing Audiences,

Constructing Identifies. frc.sagepub.com 
McKluskie, Kate. (1983). Women's Language and Literature: A Problem in Women Studies.Sage Journal

Moskow, Michal Anne. (2006). Language of American Talk Show Hots.Hogskolan: Trollhattan.Uddevalia Onem, Engin Evrim. (2016). A study on gender differences in the length of requests in Turkish. Journal of Language and Linguistics Studies. Vol 12 (2). www.jlls.org

Signes, Carmen Gregori. (2000). The Tabloid Talk Show As A Quasi-Conversational Type of Face To-Face Interaction. International Pragmatics Association.

Uddin, Md Nesar \& Mahmuda Sharmin. (2019). The Role of Gender in TV Talk Show Discourse in

Bangladesh: A Conversational Analysis of Hosts' InteractionManagement.Vol 9 (6). ijel.ccsenet.org 